\title{
Psychological impact of visible differences in patients with congenital craniofacial anomalies
}

\author{
Varun Pratap Singh ${ }^{1 *}$ and Timothy P Moss ${ }^{2}$
}

\begin{abstract}
Background: Patients with craniofacial anomalies often have appearance concerns and related social anxiety which can affect their quality of life. This study assessed the psychological impact of facial and dental appearance in patients with craniofacial anomalies in comparison to a general population control group.

Methods: The study involved 102 adult patients (51\% male) with congenital craniofacial anomalies and 102 controls (49\% male). Both groups completed the Nepali version of Derriford Appearance Scale (DAS) and the Psychological Impact of Dental Aesthetic Questionnaire (PIDAQ) in a clinical setting to assess appearance-related distress, avoidance, and anxiety.

Results: There was a significant difference between patients and controls on both PIDAQ (mean score for patients $33.25 \pm 9.45$ while for controls $27.52 \pm 5.67, p<0.001$ ) and DAS59 scores (mean score for patients $159.16 \pm 31.54$ while for controls $77.64 \pm 6.57, p<0.001$ ), indicating that patients experienced greater negative psychological impact of living with their appearance (PIDAQ) and more appearance-related distress (DAS) than controls. DAS scores were not associated with gender. There was no association of the place of residence (rural vs. urban) with PIDAQ or DAS59 scores.

Conclusions: There is a significant psychological impact of altered facial and dental appearance in patients with craniofacial anomalies compared to controls. There was no effect of locality (rural/urban) on the psychological impact of facial and dental appearance in patients.
\end{abstract}

Keywords: Craniofacial anomalies; Dental aesthetics; Facial aesthetics; Orthodontic; Psychosocial; Derriford

\section{Background}

Craniofacial anomalies can be defined as the conditions that encompass all congenital deformities of the cranium and face. More specifically, however, the term has come to imply congenital deformities of the head and face that interfere with physical and mental well-being [1].

The spectrum of craniofacial anomalies is very diverse, and the most common conditions include (but not restricted to) cleft lip and/or palate, craniosynostosis (which may be associated with Crouzon's syndrome or Apert's syndrome), otomandibular anomalies (Treacher Collins syndrome), CHARGE associations, holoprosencephaly, Stickler syndrome, and fetal alcohol syndrome $[2,3]$. The clinical features include a spectrum of deformities of the craniofacial region including cranium

\footnotetext{
* Correspondence: varundc@gmail.com

'Department of Orthodontics and Dentofacial Orthopedics, Nobel Medical

College and Teaching Hospital, Kanchanbari, Biratnagar 56700, Nepal

Full list of author information is available at the end of the article
}

and cranial sutures, and deformity of skull shape and facial bones including the maxilla, mandible, zygomatic arches, nose, eyes, ears, lips, and teeth [4-10].

Patients with abnormal facial appearance often have to face social discrimination. Individuals with abnormal facial appearance are typically considered to be less attractive and are often stereotypically considered as less capable, less intelligent, and less honest. Their facial appearance interferes with personal life, employability, and social interaction. Many investigations have shown that these disfiguring conditions can lead to various psychosocial problems such as high level of social anxiety and social avoidance, and poorer quality of life [11-13].

The potential problems in this patient group are further compounded by an increased prevalence of dental anomalies and malocclusion [14-18]. The best treatment

\section{实}

(C) 2015 Singh and Moss; licensee Springer. This is an open access article distributed under the terms of the Creative Commons Attribution License (http://creativecommons.org/licenses/by/4.0), which permits unrestricted use, distribution, and reproduction in any medium, provided the original work is properly credited. 
approach is multidisciplinary, which includes teamwork and support from various specialties. During almost all phases of treatment, dental services are needed and orthodontists are almost always needed from early treatment until late adult life [19]. Good facial and dental aesthetics may have a beneficial role on behavior and self-esteem. Clinicians are expected to produce evidence of the quality of care they deliver. To this end, it is necessary to use standardized, valid, and reliable psychological as well as clinical measures to evaluate outcomes [20-22].

The research in this area is somewhat conflicting and suffers various lacunae for methodological reasons. These include inconsistency in psychometric scales and constructs used, the lack of validity and reliability in many of the measures, small sample sizes, and no subcategorization of anomalies among other methodological errors [23]. Investigators have highlighted the need to move towards a 'social science model' from a 'medical model' [24-27].

This study was undertaken to assess the impact of psychological adjustment due to altered facial and dental appearance in patients with craniofacial anomalies utilizing the Derriford Appearance Scale [28] and Psychological Impact of Dental Aesthetic Questionnaire (PIDAQ) [20] which are specially designed for evaluating the psychological adjustment in people with visible differences in appearance. There are few such studies utilizing the Derriford Appearance Scale [29] and no study studying the psychological impact of facial and dental aesthetics together.

There is a strong prima facie case for comparing rural and urban populations with regard to appearance satisfaction in Nepal. There are known differences in healthcare access, service utilization, and geographic distribution of providers and services in healthcare in Nepal, with rural communities typically experiencing greater difficulties than urban comparators [30]. Given the potential for increased social isolation on one hand, but possibility of reduced prevalence of contemporary appearance pressures in more isolated communities on the other, and the likely relation between this and appearance expectations and outcomes, we included an exploratory investigation of rural versus urban populations within this study.

The objectives of this study were therefore:

1. To assess the psychological impact of facial and dental appearance in patients with craniofacial anomalies in comparison to a general population sample.

2. To explore the relationship between urban and rural residence in relation to psychosocial impact of facial and dental anomalies.
The following hypotheses were put forward:

- H1 - There is a psychosocial impact of facial and dental appearance on patients with craniofacial anomalies.

- H2 - There is a difference in psychosocial impact of facial and dental appearance of rural and urban patients.

\section{Methods}

This study was conducted in two steps. The first step included translation and validation of the instruments PIDAQ and DAS59 in the target population. This part is described in detail as published data elsewhere [31,32]. The second step included assessment of patients with craniofacial anomalies reporting for orthodontic treatment using these validated instruments.

The study was conducted in the Department of Orthodontics, BP Koirala Institute of Health Sciences, Dharan, Nepal, from 1 February 2011 to 30 October 2012. Ethical clearance was obtained from Institutional Ethical Committee, B.P. Koirala Institute of Health Sciences, Dharan, Nepal, reference no. Acd/216/068/069, and principles from the Declaration of Helsinki were followed. The study population consisted of adult patients with congenital craniofacial anomalies visiting the Department of Orthodontics during the above said period. The study also included similar patients who were referred/or reported to the orthodontic OPD during 2005 to 2010 and did not undergo orthodontic treatment and patients from the waiting list for whom treatment had not started. The inclusion criteria were adult patients with congenital craniofacial anomalies aged 18 to 30 years. Patients with acquired or traumatic facial disfigurement and history of orthodontic treatment, people who did not have the capacity to offer informed consent, and people who could not read the test booklet unaided were excluded.

\begin{tabular}{|c|c|c|}
\hline Serial number & Craniofacial anomalies & Number (102) \\
\hline 1. & Isolated cleft lip/palate & 45 \\
\hline 2. & Isolated craniosynostosis & 22 \\
\hline 3. & Hemifacial microsomia & 10 \\
\hline 4. & Ectodermal dysplasia & 4 \\
\hline 5. & Cleidocranial dysplasia & 3 \\
\hline 6. & Treacher Collins syndrome & 6 \\
\hline 7. & Pierre Robin syndrome & 4 \\
\hline 8. & Crouzon's syndrome & 4 \\
\hline 9. & Apert's syndrome & 4 \\
\hline
\end{tabular}


There were 112 patients satisfying the inclusion and exclusion criteria. All were invited to participate, and 102 (91\%) agreed to participate in the study. Written informed consent was obtained from all the participants. There were 52 males and 50 females with a mean age of 24.78 years $($ s.d. $=2.5)$. Forty-six were from rural areas and 56 from urban. Details regarding the classification of patients according to the craniofacial anomalies are presented in Table 1. A similar number of controls, 50 males and 52 females (mean age 24.99 years, s.d. $=2.73$ ), were selected as a convenience sample from the university students and employees who have no acquired or congenital facial deformity. Thirty-nine were from rural areas and 63 from urban. Participants with severe malocclusion as assessed by an orthodontist were not included. The exclusion criteria were the same as those of the case groups.
The questionnaire pack consisted of

1. An introductory section with basic demographic information including age, sex, and place of residence in terms of rural and urban.

2. Nepali version of DAS consisting of 59 items. Each item response is marked based on a Likert scale from 1 to 4 , with 1 indicating 'almost never' and 4 indicating 'almost always'.

3. Nepali version of PIDAQ consisting of 23 items arranged in four domains. Each item response is marked based on a Likert scale from 0 to 4 , with 0 indicating 'not at all' and 4 indicating 'very strongly.'

These questionnaires were administered to the participants by one author who is well trained in this procedure. The patients were seated in a private room, in the

Table 2 Differences between the DAS 59 and PIDAQ scores for patients and controls

\begin{tabular}{|c|c|c|c|c|}
\hline Items & Group & Mean & Standard deviation & $p$ value \\
\hline \multirow[t]{2}{*}{ General self-consciousness } & Cases & $49.29^{* * *}$ & 10.8 & $<0.001$ \\
\hline & Controls & $21.84^{* * *}$ & 3.2 & \\
\hline \multirow[t]{2}{*}{ Social self-consciousness } & Cases & $58.23^{* * *}$ & 14.17 & $<0.001$ \\
\hline & Controls & $22.8^{* * *}$ & 2.40 & \\
\hline \multirow[t]{2}{*}{ Sexual and bodily self-consciousness } & Cases & $24.26^{* * *}$ & 5.98 & $<0.001$ \\
\hline & Controls & $8.77^{* * *}$ & 2.09 & \\
\hline \multirow[t]{2}{*}{ Negative self-concept } & Cases & $9.65^{* * *}$ & 3.16 & $<0.001$ \\
\hline & Controls & $16.91^{* * *}$ & 1.17 & \\
\hline \multirow[t]{2}{*}{ Facial self-consciousness } & Cases & $12.02^{* * *}$ & 2.50 & $<0.001$ \\
\hline & Controls & $4.66^{* * *}$ & 1.06 & \\
\hline \multirow[t]{2}{*}{ Physical } & Cases & $5.71^{* * *}$ & 1.60 & $<0.001$ \\
\hline & Controls & $2.65^{* * *}$ & 0.99 & \\
\hline \multirow[t]{2}{*}{ Total DAS score } & Cases & $159.16^{* * *}$ & 31.54 & $<0.001$ \\
\hline & Controls & $77.64^{* * *}$ & 6.57 & \\
\hline \multirow[t]{2}{*}{ Dental self-confidence } & Cases & $12.84^{* * *}$ & 3.10 & $<0.001$ \\
\hline & Controls & $11.11^{* * *}$ & 2.91 & \\
\hline \multirow[t]{2}{*}{ Social impact } & Cases & $7.2^{* *}$ & 3.36 & 0.004 \\
\hline & Controls & $6.1^{* *}$ & 1.72 & \\
\hline \multirow[t]{2}{*}{ Psychological impact } & Cases & $6.33^{* * *}$ & 2.86 & $<0.001$ \\
\hline & Controls & $5.03^{* * *}$ & 1.92 & \\
\hline \multirow[t]{2}{*}{ Aesthetic concern } & Cases & $6.88^{* * *}$ & 2.76 & $<0.001$ \\
\hline & Controls & $5.28^{* * *}$ & 1.62 & \\
\hline \multirow[t]{2}{*}{ Dental self-consciousness } & Cases & $8.56^{* * *}$ & 4.20 & $<0.001$ \\
\hline & Controls & $6.65^{* * *}$ & 1.99 & \\
\hline \multirow[t]{2}{*}{ Total PIDAQ score } & Cases & $33.25^{* * *}$ & 9.45 & $<0.001$ \\
\hline & Controls & $27.52^{* * *}$ & 5.67 & \\
\hline
\end{tabular}

* correlation is significant at the 0.05 level.

** correlation is significant at the 0.01 level.

${ }^{* * *}$ correlation is significant at the 0.001 level. 
Department of Orthodontics, and were asked to fill the questionnaire pack without the aid of the investigators, minimizing the likelihood of demand characteristics biasing responses. Participants were paid legitimate expenses incurred in attending the session but otherwise offered no incentive to participate. Payment was entirely independent of participants' responses and, as such, unlikely to induce any bias in responding. Furthermore, the level of remuneration was such that participants did not profit from participation and such were not induced to a particular response set.

\section{Statistical procedures}

Descriptive statistics was calculated for the demographic data. Independent $t$ tests were used to evaluate the differences between cases and controls for scores of DAS59 and PIDAQ scales. Independent $t$ tests were used to assess the effect of gender (male vs. female) and locality (rural vs. urban) on PIDAQ and DAS59 scores in both cases and controls. Bonferroni corrections were applied to the results to correct for type 1 errors resulting from multiple comparisons.

\section{Results}

There was a significant difference between patients and controls on PIDAQ (mean score for patients $=33.25$, s.d. $=9.45 ;$ mean for controls $=27.52$, s.d. $=5.67 ; p<0.001$ ) and DAS59 scores (mean score for patients $=159.16$, s.d. $=31.54 ;$ mean for controls $=77.64$, s.d. $=6.57$; $p<0.001$ ) (Table 2). The patients' scores were significantly higher than those of controls on both the PIDAQ and DAS59 scales.

\section{Gender}

There was no effect of gender except for sub-domains of PIDAQ 'psychological impact' and 'aesthetic

Table 3 Effect of gender on PIDAQ and DAS59 scores in patients

\begin{tabular}{|c|c|c|c|c|c|}
\hline Domain & Sex & Mean & Standard deviation & Standard error mean & $p$ value \\
\hline \multirow[t]{2}{*}{ General self-consciousness } & Male & 49.29 & 10.815 & 1.5 & 0.996 \\
\hline & Female & 49.3 & 10.998 & 1.555 & \\
\hline \multirow[t]{2}{*}{ Social self-consciousness } & Male & 58.73 & 14.096 & 1.955 & 0.715 \\
\hline & Female & 57.7 & 14.379 & 2.033 & \\
\hline \multirow[t]{2}{*}{ Sexual and bodily self-consciousness } & Male & 24.44 & 5.992 & 0.831 & 0.762 \\
\hline & Female & 24.08 & 6.037 & 0.854 & \\
\hline \multirow[t]{2}{*}{ Negative self-concept } & Male & 9.52 & 3.032 & 0.421 & 0.68 \\
\hline & Female & 9.78 & 3.328 & 0.471 & \\
\hline \multirow[t]{2}{*}{ Facial self-consciousness } & Male & 12.23 & 2.51 & 0.348 & 0.388 \\
\hline & Female & 11.8 & 2.507 & 0.355 & \\
\hline \multirow[t]{2}{*}{ Physical } & Male & 5.85 & 1.638 & 0.227 & 0.372 \\
\hline & Female & 5.56 & 1.58 & 0.223 & \\
\hline \multirow[t]{2}{*}{ Total DAS } & Male & 160.06 & 31.585 & 4.38 & 0.77 \\
\hline & Female & 158.22 & 31.799 & 4.497 & \\
\hline \multirow[t]{2}{*}{ Dental self-confidence } & Male & 12.69 & 2.86 & 0.397 & 0.62 \\
\hline & Female & 13 & 3.369 & 0.476 & \\
\hline \multirow[t]{2}{*}{ Social impact } & Male & 6.98 & 3.006 & 0.417 & 0.512 \\
\hline & Female & 7.42 & 3.709 & 0.525 & \\
\hline \multirow[t]{2}{*}{ Psychological impact } & Male & $5.44^{* * *}$ & 2.2 & 0.305 & 0.001 \\
\hline & Female & $7.26^{* * *}$ & 3.18 & 0.45 & \\
\hline \multirow[t]{2}{*}{ Aesthetic concern } & Male & $6.13^{* *}$ & 2.385 & 0.331 & 0.005 \\
\hline & Female & $7.66^{* *}$ & 2.939 & 0.416 & \\
\hline \multirow[t]{2}{*}{ Dental self-consciousness } & Male & 8.17 & 4.218 & 0.585 & 0.348 \\
\hline & Female & 8.96 & 4.204 & 0.595 & \\
\hline \multirow[t]{2}{*}{ Total PIDAQ score } & Male & $31.25^{*}$ & 7.963 & 1.104 & 0.028 \\
\hline & Female & $35.34^{*}$ & 10.458 & 1.479 & \\
\hline
\end{tabular}

* correlation is significant at the 0.05 level.

** correlation is significant at the 0.01 level.

${ }^{* * *}$ correlation is significant at the 0.001 level. 
Table 4 Effect of gender on PIDAQ and DAS59 scores in controls

\begin{tabular}{|c|c|c|c|c|c|}
\hline Domain & Sex & Mean & Standard deviation & Standard error mean & $p$ value \\
\hline \multirow[t]{2}{*}{ General self-consciousness } & Male & 21.84 & 3.046 & 0.431 & 0.992 \\
\hline & Female & 21.85 & 3.438 & 0.477 & \\
\hline \multirow[t]{2}{*}{ Social self-consciousness } & Male & 22.7 & 2.667 & 0.377 & 0.67 \\
\hline & Female & 22.9 & 2.135 & 0.296 & \\
\hline \multirow[t]{2}{*}{ Sexual and bodily self-consciousness } & Male & 8.92 & 2.311 & 0.327 & 0.494 \\
\hline & Female & 8.63 & 1.869 & 0.259 & \\
\hline \multirow[t]{2}{*}{ Negative self-concept } & Male & 16.98 & 1.22 & 0.173 & 0.566 \\
\hline & Female & 16.85 & 1.127 & 0.156 & \\
\hline \multirow[t]{2}{*}{ Facial self-consciousness } & Male & 4.56 & 0.812 & 0.115 & 0.371 \\
\hline & Female & 4.75 & 1.266 & 0.176 & \\
\hline \multirow[t]{2}{*}{ Physical } & Male & 2.58 & 0.883 & 0.125 & 0.506 \\
\hline & Female & 2.71 & 1.091 & 0.151 & \\
\hline \multirow[t]{2}{*}{ Total DAS } & Male & 77.58 & 6.843 & 0.968 & 0.932 \\
\hline & Female & 77.69 & 6.379 & 0.885 & \\
\hline \multirow[t]{2}{*}{ Dental self-confidence } & Male & 11.18 & 2.833 & 0.401 & 0.808 \\
\hline & Female & 11.04 & 3.016 & 0.418 & \\
\hline \multirow[t]{2}{*}{ Social impact } & Male & 6 & 1.702 & 0.241 & 0.575 \\
\hline & Female & 6.19 & 1.749 & 0.243 & \\
\hline \multirow[t]{2}{*}{ Psychological impact } & Male & 5.22 & 1.93 & 0.273 & 0.328 \\
\hline & Female & 4.85 & 1.914 & 0.265 & \\
\hline \multirow[t]{2}{*}{ Aesthetic concern } & Male & 5.5 & 1.681 & 0.238 & 0.19 \\
\hline & Female & 5.08 & 1.557 & 0.216 & \\
\hline \multirow[t]{2}{*}{ Dental self-consciousness } & Male & 6.84 & 1.707 & 0.241 & 0.34 \\
\hline & Female & 6.46 & 2.236 & 0.31 & \\
\hline \multirow[t]{2}{*}{ Total PIDAQ score } & Male & 27.9 & 5.319 & 0.752 & 0.509 \\
\hline & Female & 27.15 & 6.024 & 0.835 & \\
\hline
\end{tabular}

concern,' where females had higher scores than males (mean, $\mathrm{M}=5.44$ (s.d. $=2.2$ ), $\mathrm{F}=7.26$ (s.d. = 3.18), $p=0.001$; $\mathrm{M}=4.27$ (s.d. = 1.99), $\mathrm{F}=5.32$ (s.d. = 2.55), $p=0.005$ ). However, the total PIDAQ score was significantly higher in females as compared to males (mean, $\mathrm{M}=31.25$ (s.d. $=7.96$ ), $\mathrm{F}=35.34$ (s.d. $=10.45), p=0.02)$. DAS scores were not differentiated by gender (Table 3). In controls, there was no difference in PIDAQ and DAS59 scores by gender (Table 4).

\section{Rural versus urban}

There was no difference in the place of residence (rural vs. urban) with either PIDAQ or DAS59 scores in patients (Tables 5 and 6), nor for subscales of each of these measures following Bonferroni control for multiple comparisons.

\section{Discussion}

In comparison to general population controls, craniofacial patients with orthodontic and orthognathic concerns showed greater appearance-related distress, according to valid and reliable psychometric scales. For general distress, there was also no difference between urban and rural participants. Females did not demonstrate more distress than males when assessed using the DAS59. However, on two of the dental-specific scales of the PIDAQ, 'psychological impact' and 'aesthetic concern', female patients reported more distress than male patients.

Some studies and reviews suggest that there are few significant differences in overall psychological functioning of patients with craniofacial anomalies as compared to general population norms. However, these studies report some difficulty in a particular area of functioning [33-39]. There is substantial evidence of appearance concern due to dissatisfaction with facial appearance in patients with craniofacial anomalies [40-44]. This dissatisfaction with facial appearance may lead to behavioral difficulties [45-48].

Many studies point out that the adult population is at risk of psychosocial problems due to concerns regarding their facial appearance [49-52]. The results of this study 
Table 5 Effect of locality (rural/urban) on PIDAQ and DAS59 scores in patients

\begin{tabular}{|c|c|c|c|c|c|}
\hline Domain & Rural/urban & Mean & Standard deviation & Standard error mean & Significance \\
\hline \multirow[t]{2}{*}{ General self-consciousness } & Rural & 49.91 & 10.167 & 1.499 & 0.604 \\
\hline & Urban & 48.79 & 11.447 & 1.53 & \\
\hline \multirow[t]{2}{*}{ Social self-consciousness } & Rural & 59.07 & 13.401 & 1.976 & 0.59 \\
\hline & Urban & 57.54 & 14.864 & 1.986 & \\
\hline \multirow[t]{2}{*}{ Sexual and bodily self-consciousness } & Rural & 24.63 & 5.867 & 0.865 & 0.579 \\
\hline & Urban & 23.96 & 6.12 & 0.818 & \\
\hline \multirow[t]{2}{*}{ Negative self-concept } & Rural & 9.59 & 2.941 & 0.434 & 0.863 \\
\hline & Urban & 9.7 & 3.368 & 0.45 & \\
\hline \multirow[t]{2}{*}{ Facial self-consciousness } & Rural & 11.76 & 2.349 & 0.346 & 0.347 \\
\hline & Urban & 12.23 & 2.628 & 0.351 & \\
\hline \multirow[t]{2}{*}{ Physical } & Rural & 5.89 & 1.464 & 0.216 & 0.293 \\
\hline & Urban & 5.55 & 1.715 & 0.229 & \\
\hline \multirow[t]{2}{*}{ Total DAS } & Rural & 160.85 & 29.731 & 4.384 & 0.626 \\
\hline & Urban & 157.77 & 33.165 & 4.432 & \\
\hline \multirow[t]{2}{*}{ Dental self-confidence } & Rural & 12.7 & 3.595 & 0.53 & 0.666 \\
\hline & Urban & 12.96 & 2.669 & 0.357 & \\
\hline \multirow[t]{2}{*}{ Social impact } & Rural & 7.37 & 3.555 & 0.524 & 0.639 \\
\hline & Urban & 7.05 & 3.216 & 0.43 & \\
\hline \multirow[t]{2}{*}{ Psychological impact } & Rural & 6.13 & 2.841 & 0.419 & 0.519 \\
\hline & Urban & 6.5 & 2.892 & 0.386 & \\
\hline \multirow[t]{2}{*}{ Aesthetic concern } & Rural & 6.85 & 3.048 & 0.449 & 0.91 \\
\hline & Urban & 6.91 & 2.539 & 0.339 & \\
\hline \multirow[t]{2}{*}{ Dental self-consciousness } & Rural & 9.09 & 4.56 & 0.672 & 0.253 \\
\hline & Urban & 8.13 & 3.885 & 0.519 & \\
\hline \multirow[t]{2}{*}{ Total PIDAQ score } & Rural & 33.04 & 10.321 & 1.522 & 0.839 \\
\hline & Urban & 33.43 & 8.761 & 1.171 & \\
\hline
\end{tabular}

have supported the hypothesis that adults who have craniofacial anomalies have negative psychosocial impact due to facial and dental appearance. In the current study, both DAS and PIDAQ scores were significantly higher in patients than in controls, indicating that patients experienced negative psychological impact and more distress (Table 2).

In this study, it was shown that there were no significant differences in DAS59 scores for male versus female patients. This is in accordance with Kiyak and Bell [53], who stated that there were no gender differences on psychological variables in the pre-surgical assessment of patients needing orthognathic surgery, though counter to other evidence regarding self-consciousness of appearance, which typically shows more distress among female participants [28]. In the analysis of the PIDAQ, it was interesting that there was statistically significant difference for overall psychological impact of dental aesthetics on two PIDAQ subscales, though when a Bonferroni correction for multiple comparisons is applied to the data, the difference becomes non-significant. However, the specific psychological impact upon males and females assessed using PIDAQ subscales does significantly differ, with females having higher scores for both (Table 3). It may be hypothesized that females are socialized to be more concerned and dissatisfied by their dental appearance as compared to males and to socially evaluate their appearance to a greater degree than males [54]. While it remains to be further investigated in subsequent research, it is possible that patients with craniofacial conditions are more sensitized to appearance distress than controls, and in combination with social pressure associated with gender, more distress ensues.

Contrary to our expectations, there was no effect of area of residence (rural vs. urban) on the overall psychological impact of facial and dental appearance in patients or control participants following Bonferroni correction for type 1 errors. This may indicate that aesthetic norms and pressures are not decreased by living in a less populous urban environment and that these norms are 
Table 6 Effect of locality (rural/urban) on PIDAQ and DAS59 scores in controls

\begin{tabular}{|c|c|c|c|c|c|}
\hline Domain & Rural/urban & Mean & Standard deviation & Standard error mean & Significance \\
\hline \multirow[t]{2}{*}{ General self-consciousness } & Rural & 21.46 & 2.584 & 0.414 & 0.351 \\
\hline & Urban & 22.08 & 3.58 & 0.451 & \\
\hline \multirow[t]{2}{*}{ Social self-consciousness } & Rural & 22.92 & 2.559 & 0.41 & 0.695 \\
\hline & Urban & 22.73 & 2.315 & 0.292 & \\
\hline \multirow[t]{2}{*}{ Sexual and bodily self-consciousness } & Rural & 8.33 & 2.144 & 0.343 & 0.094 \\
\hline & Urban & 9.05 & 2.027 & 0.255 & \\
\hline \multirow[t]{2}{*}{ Negative self-concept } & Rural & $16.62^{*}$ & 1.206 & 0.193 & 0.044 \\
\hline & Urban & $17.1^{*}$ & 1.118 & 0.141 & \\
\hline \multirow[t]{2}{*}{ Facial self-consciousness } & Rural & 4.49 & 0.823 & 0.132 & 0.208 \\
\hline & Urban & 4.76 & 1.187 & 0.15 & \\
\hline \multirow[t]{2}{*}{ Physical } & Rural & 2.69 & 0.977 & 0.157 & 0.719 \\
\hline & Urban & 2.62 & 1.007 & 0.127 & \\
\hline \multirow[t]{2}{*}{ Total DAS } & Rural & 76.51 & 6.476 & 1.037 & 0.176 \\
\hline & Urban & 78.33 & 6.594 & 0.831 & \\
\hline \multirow[t]{2}{*}{ Dental self-confidence } & Rural & 11.31 & 3.262 & 0.522 & 0.588 \\
\hline & Urban & 10.98 & 2.697 & 0.34 & \\
\hline \multirow[t]{2}{*}{ Social impact } & Rural & 5.82 & 1.819 & 0.291 & 0.201 \\
\hline & Urban & 6.27 & 1.648 & 0.208 & \\
\hline \multirow[t]{2}{*}{ Psychological impact } & Rural & 5.44 & 1.917 & 0.307 & 0.093 \\
\hline & Urban & 4.78 & 1.896 & 0.239 & \\
\hline \multirow[t]{2}{*}{ Aesthetic concern } & Rural & $5.72^{*}$ & 1.701 & 0.272 & 0.033 \\
\hline & Urban & $5.02^{*}$ & 1.529 & 0.193 & \\
\hline \multirow[t]{2}{*}{ Dental self-consciousness } & Rural & 6.69 & 1.838 & 0.294 & 0.858 \\
\hline & Urban & 6.62 & 2.098 & 0.264 & \\
\hline \multirow[t]{2}{*}{ Total PIDAQ score } & Rural & 28.28 & 6.017 & 0.964 & 0.288 \\
\hline & Urban & 27.05 & 5.446 & 0.686 & \\
\hline
\end{tabular}

* correlation is significant at the 0.05 level.

** correlation is significant at the 0.01 level.

***correlation is significant at the 0.001 level.

pervasive. It also suggests that the availability of complex cosmetic dentistry in urban Nepal has not fundamentally shifted the discrepancy between perceived dental appearance ideals and actuality.

There are some methodological limitations inherent in this study which should be considered when generalizing findings. Firstly, the age of participants in both the experimental and control groups was low compared to a random sample of the general population. It is feasible that as people age beyond the age boundaries within this study, they will become differentially sensitive to differences of appearance due to craniofacial anomalies. A second limitation lies in the nature of the comparison group. As university students and employees, it is feasible that they are not directly equivalent to the patient group in cognitive and social domains. However, there is no a priori reason to assume that these differences would be related to subjective feelings or coping around appearance, and as such, the use of this comparison sample is justified. The comparison between rural and urban samples was not significant. This may, as described, reflect a genuine lack of difference. However, it is also worth reflecting on the categorization of these groups. For pragmatic reasons, current residence was used as the variable to code participants as 'urban' or 'rural.' What remains to be investigated in further work is the degree of stability of these categories. It may well be that those in the 'urban' category have been previously socialized in rural areas during formative periods of their development, and vice versa for those in the 'rural' category. If this were the case, differences between our groups would be less apparent than might be otherwise expected. In terms of the study instruments, both PIDAQ and DAS are robust measures. However, it is possible that there could be aspects of appearance sensitivity which are not identified in these measures. 


\section{Conclusions}

1. There is a significant psychological impact of altered facial and dental appearance in patients with craniofacial anomalies.

2. There was no significant effect of gender on the psychological impact of facial appearance in patients; however, significant negative psychological impact of dental appearance was seen in female patients.

3. There was no effect of locality (rural/urban) on the psychological impact of facial and dental appearance.

\section{Competing interests}

The authors declare that they have no competing interests.

\section{Authors' contributions}

VPS conceived the study and VPS and TPM participated in study design, VPS carried out the study, VPS and TPM carried out statistical analysis, VPS and TPM prepared the manuscript. Both authors read and approved the final manuscript.

\section{Author details}

'Department of Orthodontics and Dentofacial Orthopedics, Nobel Medical College and Teaching Hospital, Kanchanbari, Biratnagar 56700, Nepal. ${ }^{2}$ Department of Health Psychology, University of the West of England, Frenchary Campus, cold Harbour Lane, Bristol BS161QY, UK.

Received: 21 December 2014 Accepted: 28 February 2015

\section{Published online: 18 April 2015}

\section{References}

1. Marsh JL, Vannier MW. Comprehensive care for craniofacial deformities. 1st ed. CV Mosby: St. Louis; 1985.

2. World Health Organization. Addressing the global challenges of craniofacial anomalies. 2004. http://www.who.int/genomics/publications/CFA\% 20Completed\%20text.pdf. Accessed on Friday, December 20, 2013.

3. World Health Organization. Global strategies to reduce the health-care burden of craniofacial anomalies. 2002. http://whqlibdoc.who.int/publications/ 9241590386.pdf. Accessed on Friday, December 20,2013.

4. Husu E, Hove H, Farholt S, Bille M, Tranebjaerg L, Vogel I, et al. Phenotype in 18 Danish subjects with genetically verified CHARGE syndrome. Clin Genet. 2013;83(2):125-34.

5. Stavropoulos D, Tarnow P, Mohlin B, Kahnberg KE, Hagberg C. Comparing patients with Apert and Crouzon syndromes - clinical features and cranio-maxillofacial surgical reconstruction. Swed Dent J. 2012;36(1):25-34.

6. Tuna EB, Orino D, Ogawa K, Yildirim M, Seymen F, Gencay K. Craniofacial and dental characteristics of Goldenhar syndrome: a report of two cases. J Oral Sci. 2011:53:121-4.

7. Kini U, Hurst JA, Byren JC, Wall SA, Johnson D, Wilkie AO. Etiological heterogeneity and clinical characteristics of metopic synostosis: evidence from a tertiary craniofacial unit. Am J Med Genet A. 2010;152 (6):1383-9.

8. Chong DK, Murray DJ, Britto JA, Tompson B, Forrest CR, Phillips JH. A cephalometric analysis of maxillary and mandibular parameters in Treacher Collins syndrome. Plast Reconstr Surg. 2008;121(3):77-84.

9. Itthagarun A, Nair RG, Epstein JB, King NM. Fetal alcohol syndrome: case report and review of the literature. Oral Surg Oral Med Oral Pathol Oral Radiol Endod. 2007;103(3):20-5.

10. Lu DW, Shi B, Wang HJ, Zheng Q. The comparative study of craniofacial structural characteristic of individuals with different types of cleft palate. Ann Plast Surg. 2007;59(4):382-7.

11. Van den Elzen MEP, Versnel SL, Hovius SER, Passchier J, Duivenvoorden HJ, Mathijssen IMJ. Adults with congenital or acquired facial disfigurement: impact of appearance on social functioning. J Craniomaxillofac Surg. 2012;40(8):777-82.

12. Moss TP. The relationships between objective and subjective ratings of disfigurement severity, and psychological adjustment. Body Image. 2005;2(2):151-9.
13. Versnel SL, Duivenvoorden HJ, Passchier J, et al. Satisfaction with facial appearance and its determinants in adults with severe congenital facial disfigurement: a case-referent study. J Plast Reconstr Aesthet Surg. 2010:63:1642-9.

14. Da Silva DG, Costa B, Gomide MR. Prevalence of dental anomalies, ectopic eruption and associated oral malformations in subjects with Treacher Collins syndrome. Oral Surg Oral Med Oral Pathol Oral Radiol Endod. 2006;101(5):588-92.

15. Menezes R, Vieira AR. Dental anomalies as part of cleft spectrum. Cleft Palate Craniofacial journal. 2008;45(4):414-9.

16. Da Silva AP, Costa B, De Carvalho-Carrara CF. Dental anomalies of number in the permanent dentition of patients with bilateral cleft lip: radiographic study. Cleft Palate Craniofacial Journal. 2007;45(5):473-6.

17. Vettore MV, Sousa-Campose MV. Malocclusion characteristics of patients with cleft lip and/or palate. Eur J Orthod. 2011;33(3):311-7.

18. Tannure PN, Oliveira CA, Maia LC, Vieira AR, Granjeiro JM, de Castro CM. Prevalence of dental anomalies in nonsyndromic individuals with cleft lip and palate: a systematic review and meta-analysis. Cleft Palate Craniofacial Journal. 2012;49(2):194-200.

19. Lorenzzaoni D, Carcereri DL, Locks A. The importance of multi-professional, interdisciplinary care in rehabilitation and health promotion directed at patients with cleft lip/palate. Rev odonto cienc. 2010;25(2):198-203.

20. Klages U, Claus N, Wehrbein H, Zentner A. Development of a questionnaire for assessment of the psychosocial impact of dental aesthetics in young adults. Eur J Orthod. 2006;28(1):103-11.

21. Kenealy PM, Kingdon A, Richmond S, Shaw WC. The Cardiff dental study: a 20 year critical evaluation of the psychological health gain from orthodontic treatment. Br J Health Psychol. 2007;12:17-49.

22. Rappaport TG, Shalish MH, Gazil E. Psychosocial reward of orthodontic treatment in adult patients. Eur J Orthod. 2010;32(1):441-6.

23. Singh VP, Singh RK, Roy D, Baral DD, Vikram M. Guidelines and recommendations for studies on psychosocial aspects of patients with craniofacial anomalies. Mymensingh Med J. 2012;21(4):736-40.

24. Strauss R, Broder H. Directions and issues in psychosocial research and methods as applied to cleft lip and palate and craniofacial anomalies. Cleft Palate Craniofacial Journal. 1991;28(2):150-6.

25. Broder HL. Psychological research of children with craniofacial anomalies: review, critique and implications for the future. Cleft Palate Craniofacial Journal. 1979;34(5):402-4.

26. Speltz ML. Editorial: Progress and limitations in the psychological study of craniofacial anomalies. J Pediatr Psychol. 1997;22(4):433-8.

27. Endriga MC, Kapp- Simon KA. Psychological issues in craniofacial care: state of the art. Cleft Palate Craniofacial Journal. 1999:36(1):3-11.

28. Carr T, Harris D, James C. The Derriford Appearance Scale (DAS-59): a new scale to measure individual responses to living with problems of appearance. Br J Health Psychol. 2000;5:201-15.

29. Bessell A, Brough V, Clarke A, Harcourt D, Moss TP, Rumsey N. Evaluation of the effectiveness of Face IT, a computer-based psychosocial intervention for disfigurement-related distress. Psychol Health Med. 2012;17(5):565-77.

30. Rai SK, Rai G, Hirai K, Abe A, Ohno Y. The health system in Nepal - an introduction. Environ Health Prev Med. 2001;6(1):1-8.

31. Singh VP, Singh RK. Translation and validation of Nepalese version of PIDAQ J Orthod. 2014;41:6-12.

32. Singh VP, Singh RK, Moss TP, Roy DK, Baral DD. Translation and validation of the Nepalese version of Derriford appearance scale (DAS-59). Modern Plastic Surgery. 2013;3:51-6.

33. McWilliams BJ. Social and psychological problems associated with cleft palate. Clin Plast Surg. 1982;9:317-26.

34. Richman LC, Eliason M. Psychological characteristics of children with cleft lip and palate: Intellectual, achievement, behavioral and personality variables. Cleft Palate Journal. 1982;19:249-57.

35. Madison LS. Psychologic aspects of cleft lip and palate. Ear Nose and Throat Journal. 1986;65:337-41.

36. Eliason MJ. Cleft lip and palate: developmental effects. J Pediatr Nurs. 1991;6(2):107-13.

37. Tobiasen JM, Hiebert JM. Clefting and psychosocial adjustment: influence of facial aesthetics. Clin Plast Surg. 1993;20:623-31.

38. Turner SR, Rumsey N, Sandy JR. Psychological aspects of cleft lip and palate. European Orthodontic Journal. 1998;20:407-15.

39. Thompson A, Kent G. Adjusting to disfigurement: processes involved in dealing with being visibly different. Clin Psychol Rev. 2001;21:663-82. 
40. Lockhart $\mathrm{E}$. The mental health needs of children and adolescents with cleft lip and/or palate. Clin Child Psychol Psychiatry. 2003:8:7-16.

41. Tyl J, Dytrych Z, Helclová H, Scüller V, Matějcěk Z, Beránková A. Psychic and social stress of children with cleft lip and palate. Cesk Pediatr. 1990;45:532-6.

42. Richman LC. Behavior and achievement of cleft palate children. Cleft Palate Journal. 1976;13:4-10.

43. Thomas PT, Turner SR, Rumsey N, Dowell T, Sandy JR. Satisfaction with facial appearance among subjects affected by cleft. Cleft Palate Craniofacial Journal. 1997;34(3):226-31.

44. Marcusson A. Adult patients with treated complete cleft lip and palate: methodological and clinical studies. Swed Dent J. 2001;145:1-57.

45. Marcusson A, Paulin G, Ostrup L. Facial appearance in adults who had cleft. lip and palate treated in childhood. Scand J Plast Reconstr Surg Hand Surg. 2002;36:16-23.

46. Clifford E. Parental ratings of cleft palate infants. Cleft Palate Journal. 1969:6:235-44

47. Richman LC. Self-reported social, speech, and facial concerns and personality adjustment of adolescents with cleft lip and palate. Cleft Palate Journal. 1983;20:108-12.

48. Richman LC, Holmes CS, Eliason MJ. Adolescents with cleft lip and palate: self-perceptions of appearance and behavior related to personality adjustment. Cleft Palate Journal. 1985;22:93-6.

49. Ramstad T, Otten E, Shaw WC. Psychosocial adjustment in Norwegian adults who had undergone standardized treatment of complete cleft lip and palate. Part II. Self-reported problems and concerns with appearance. Scand J Plast Reconstr Surg Hand Surg. 1995:29:329-36.

50. Bernstein NR, Kapp K. Adolescents with cleft palate: body-image and psychosocial problems. Psychosomatics. 1981;22(8):697-703.

51. Cochrane VM, Slade P. Appraisal and coping in adults with cleft lip: associations with well-being and social anxiety. Br J Med Psychol. 1999; $72(4): 485-503$.

52. Berk NW, Cooper ME, Liu YE, Marazita ML. Social anxiety in Chinese adults with oral-facial clefts. Cleft Palate Craniofac J. 2001;38(2):126-33.

53. Kiyak HA, Bell R. Psychosocial considerations in surgery and orthodontics. In: Proffit WR, White Jr RP, editors. Surgical-orthodontic treatment. St. Louis: Mosby Year Book; 1991. p. 71-91.

54. Tin-Oo MM, Saddki N, Hassan N. Factors influencing patient satisfaction with dental appearance and treatments they desire to improve aesthetics. BMC Oral Health. 2011:11:6. doi:10.1186/1472-6831-11-6.

\section{Submit your manuscript to a SpringerOpen ${ }^{\circ}$ journal and benefit from:}

- Convenient online submission

- Rigorous peer review

- Immediate publication on acceptance

- Open access: articles freely available online

- High visibility within the field

- Retaining the copyright to your article 